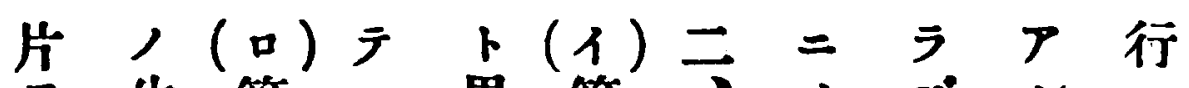

$\exists$ 生第 取前三士り方りアザ

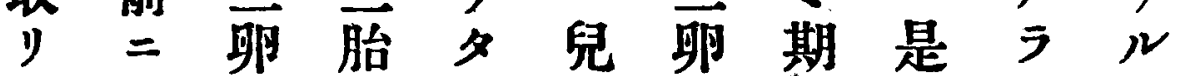
天確胞兒

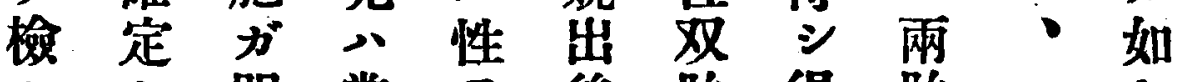
济常 $\exists$ 後胎得胎 得得力三證分。兒八場 $\sim 夕$ 同第”間第合 口羊一得 第 機 $=$ 卜 時膜性夕兒轉血渥

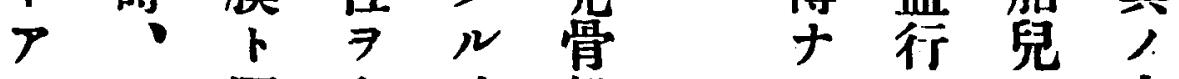
り二尿有時盤》, 中 一八絡入立端連心樞

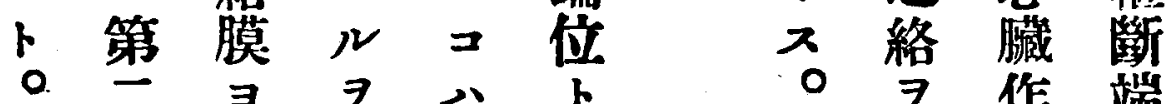
○云 $\exists$ 八 丽”点一有用寻 藤胞成方 卵y 生破儿ナ性亏

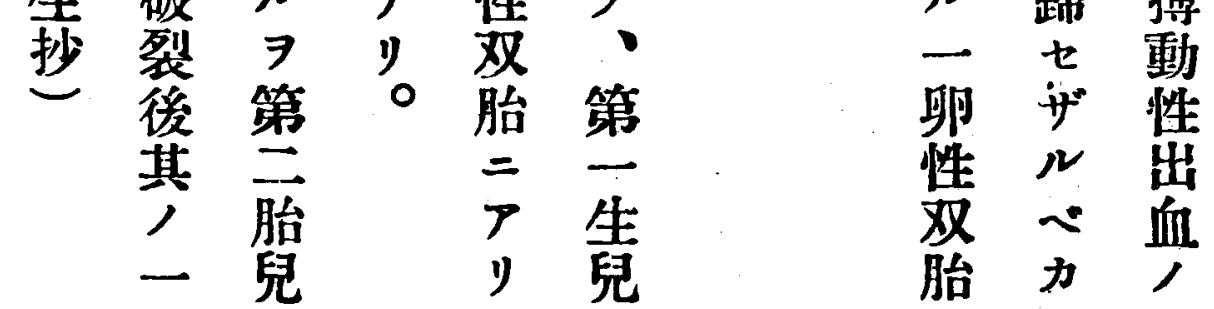

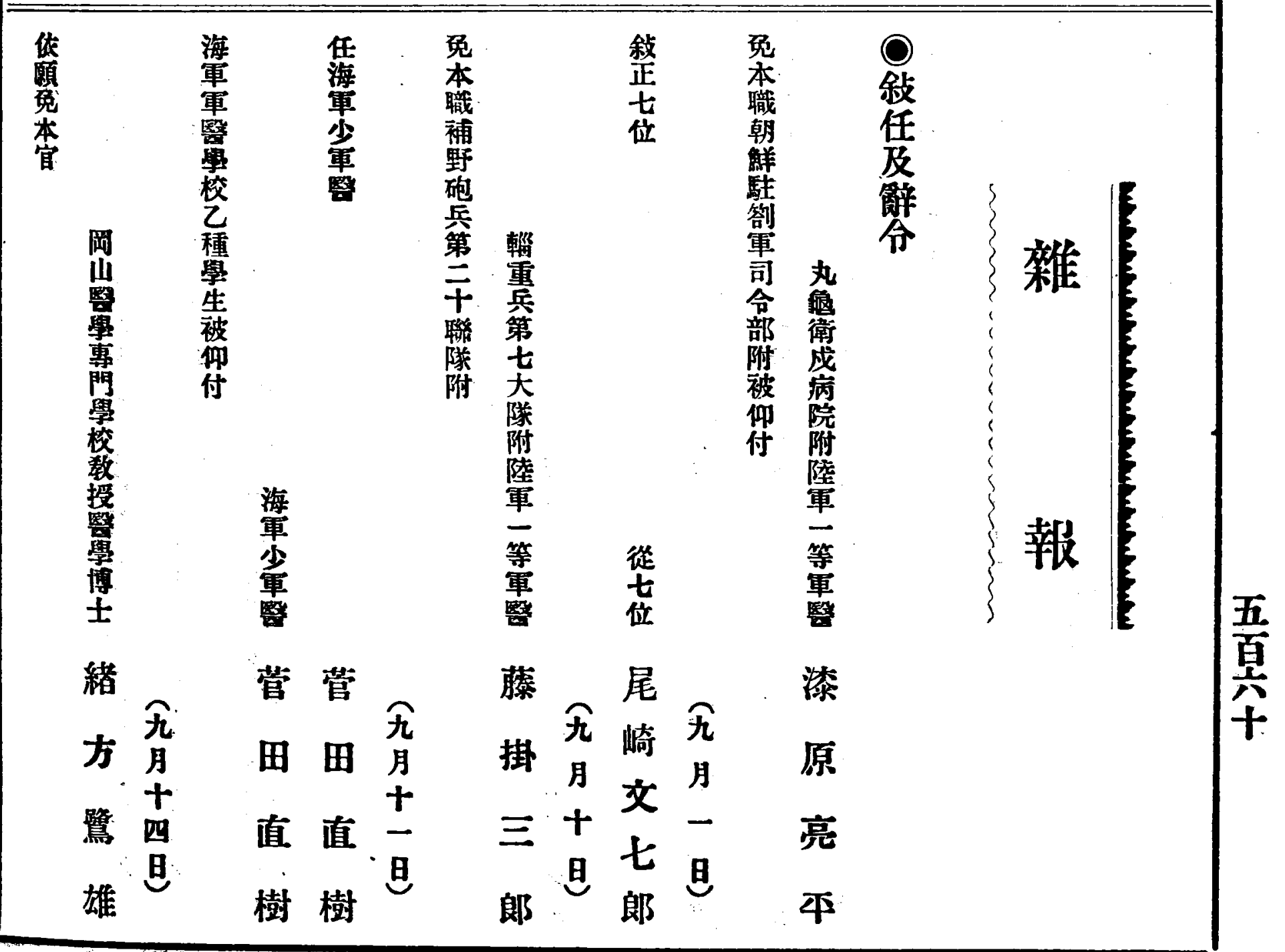




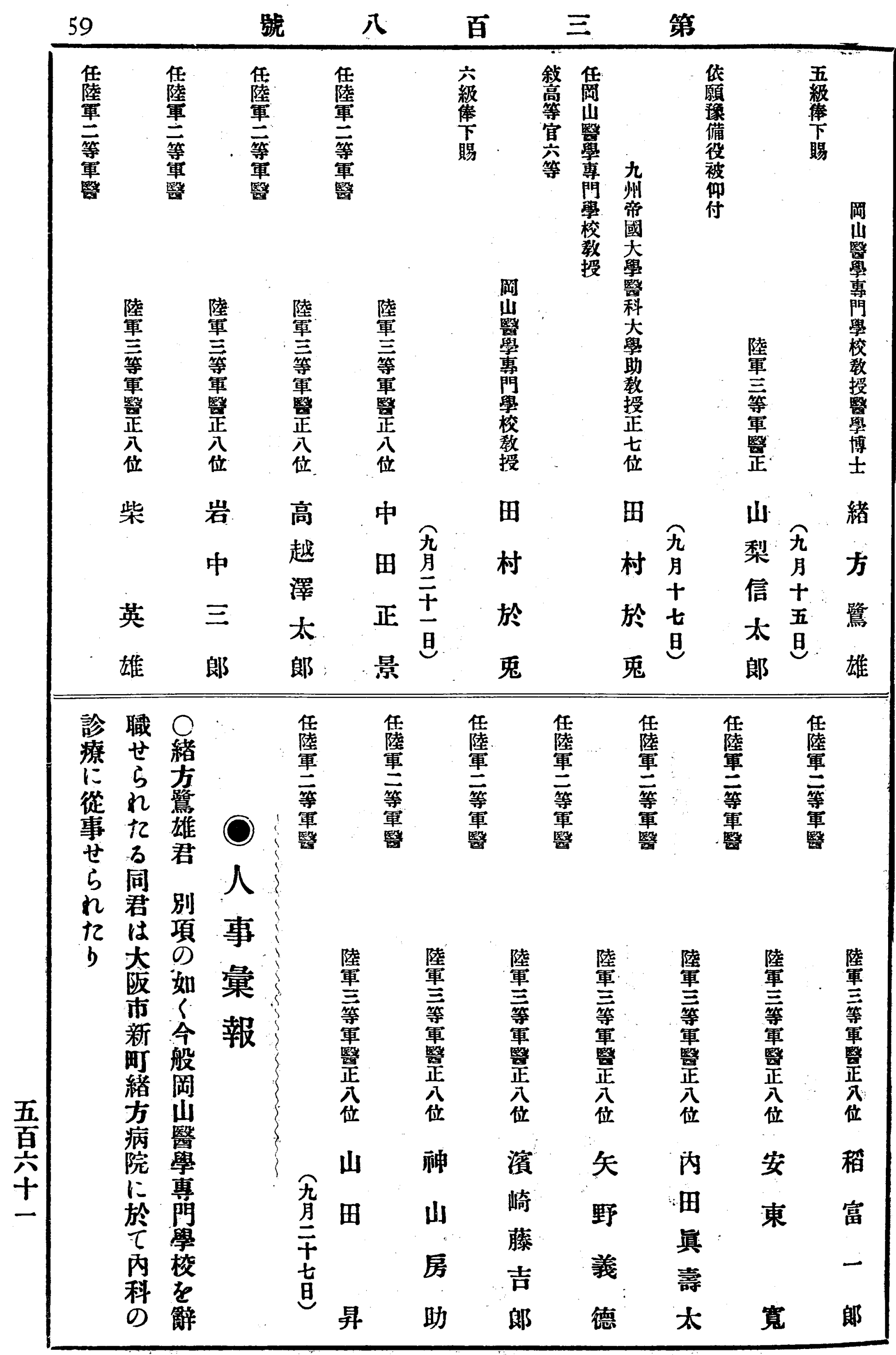




\begin{tabular}{|c|c|c|c|c|c|c|c|c|c|c|c|c|c|c|c|}
\hline 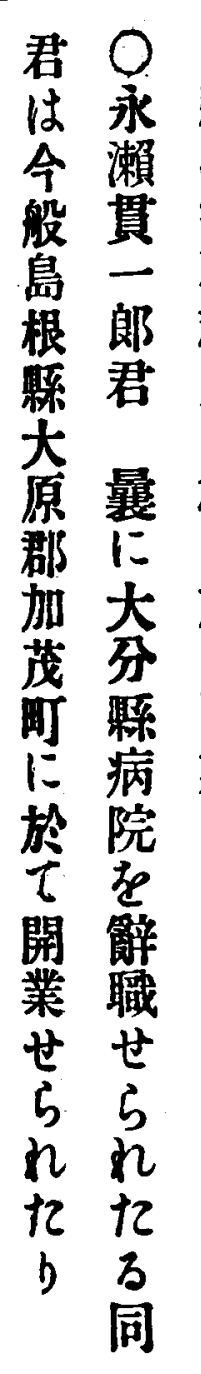 & 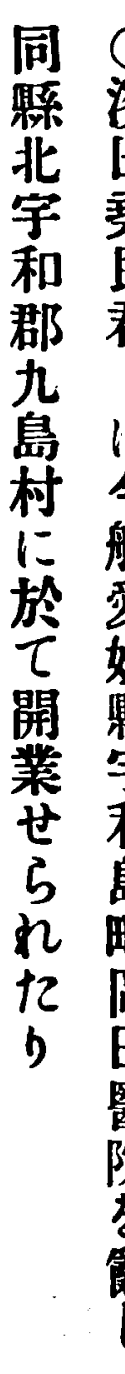 & 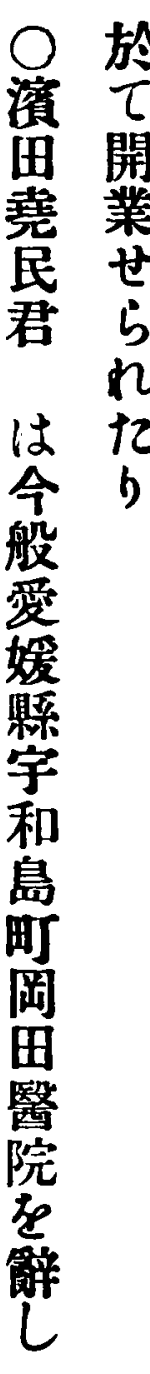 & 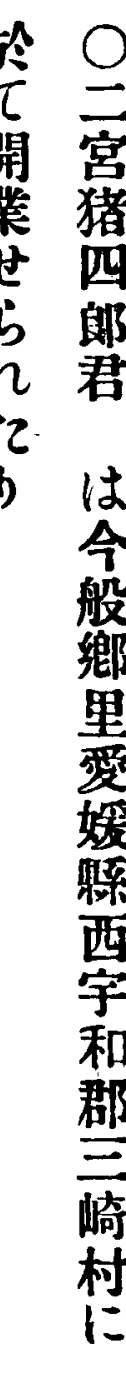 & 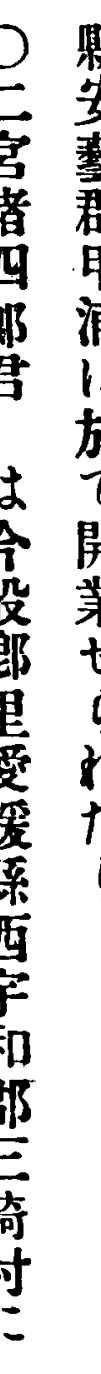 & & 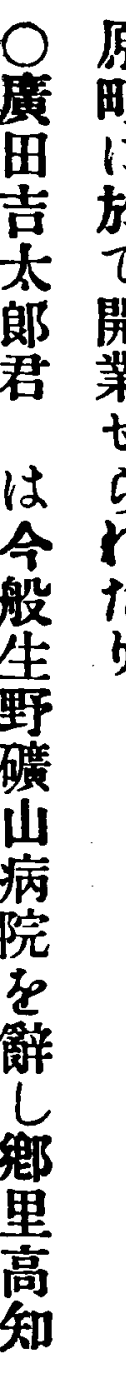 & 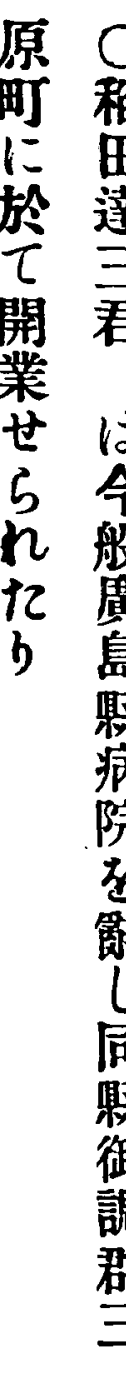 & 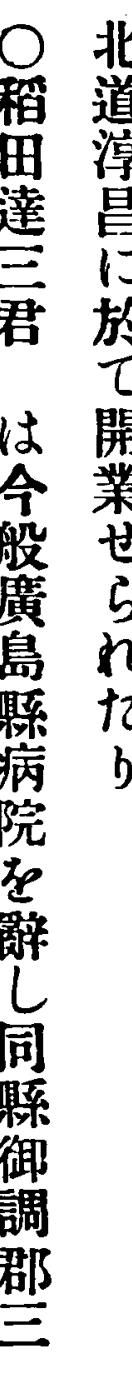 & 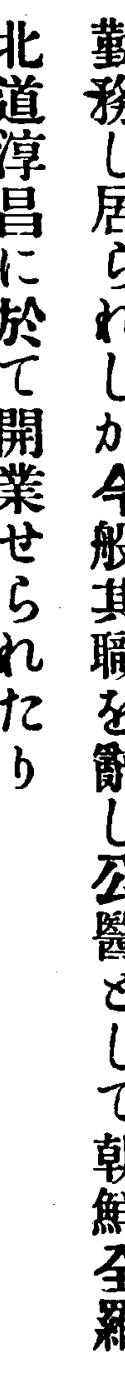 & 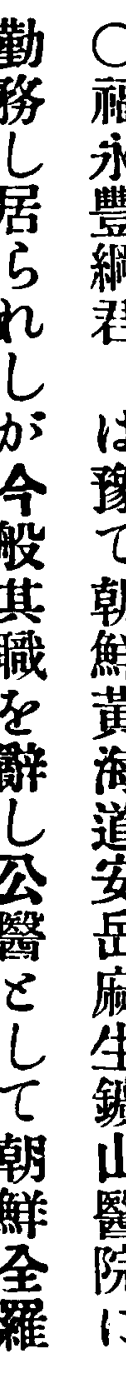 & 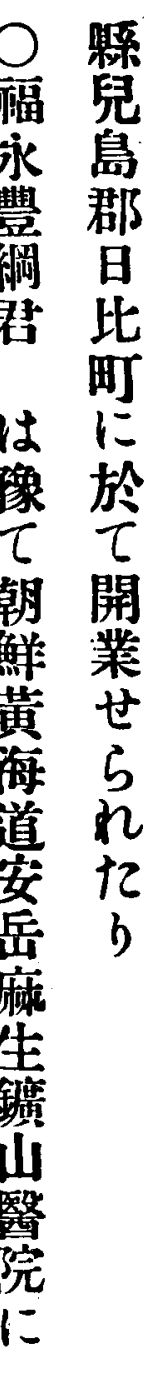 & 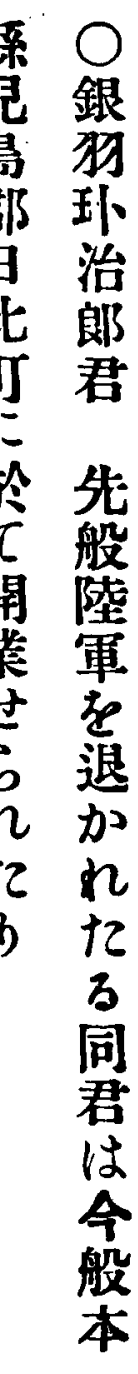 & 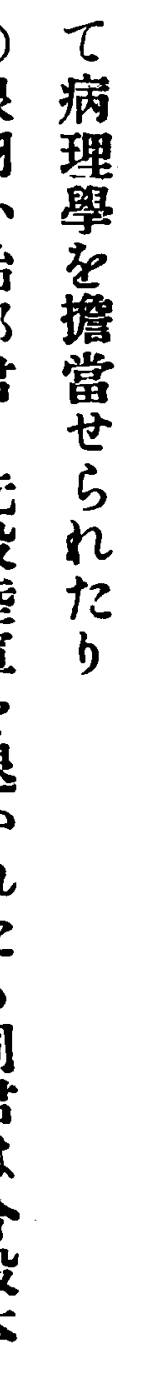 & 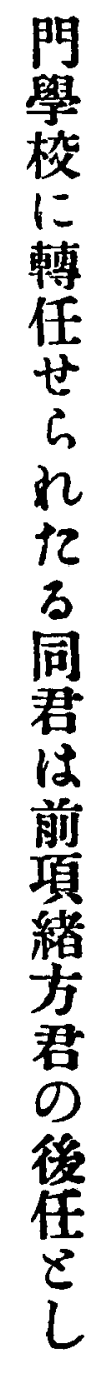 & 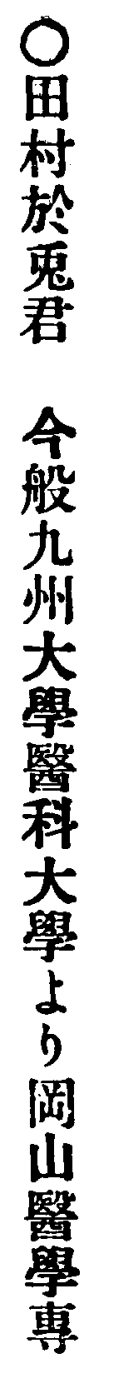 \\
\hline 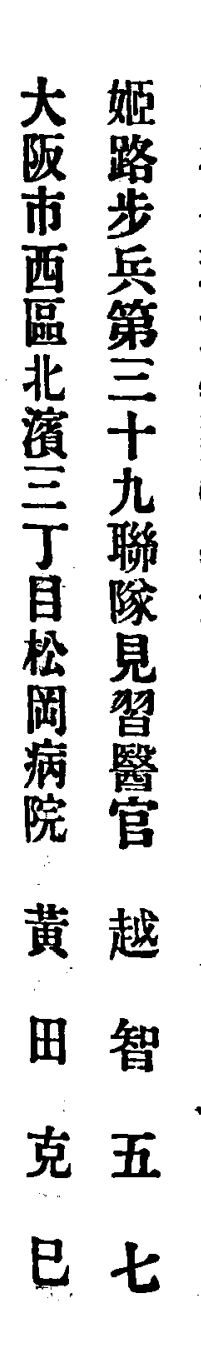 & $\begin{array}{l}\text { 京 } \\
\text { 都 } \\
\text { 醫 } \\
\text { 䔀 } \\
\text { 藥 } \\
\text { 物 } \\
\text { 學 } \\
\text { 整 } \\
\text { 至 }\end{array}$ & 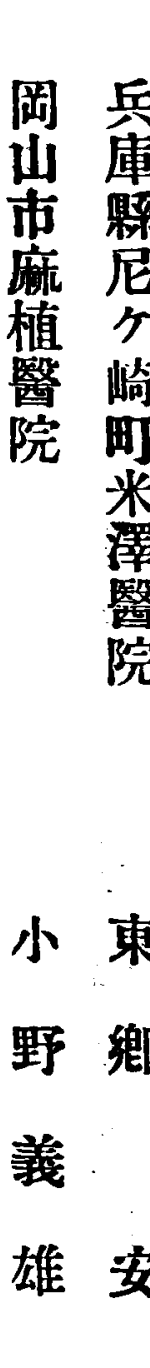 & 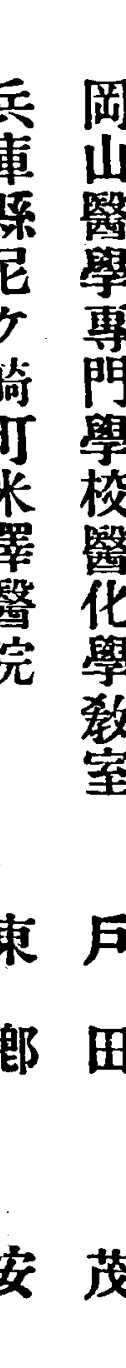 & 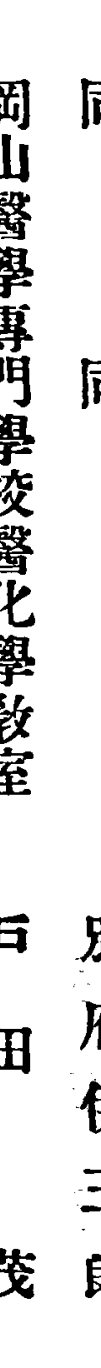 & 别 & $\begin{array}{l}\text { 西 } \\
\text { 村 } \\
\text { 敏 } \\
\text { 也 }\end{array}$ & 第 & 同 & 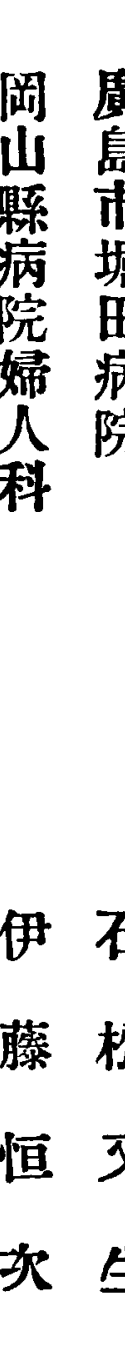 & 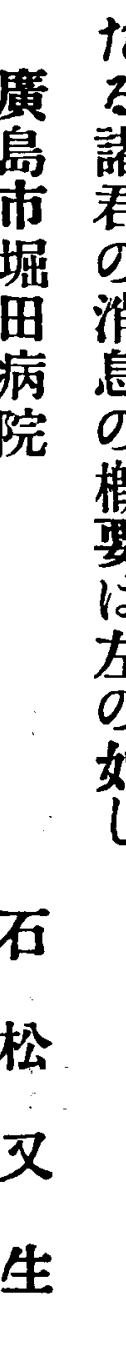 & 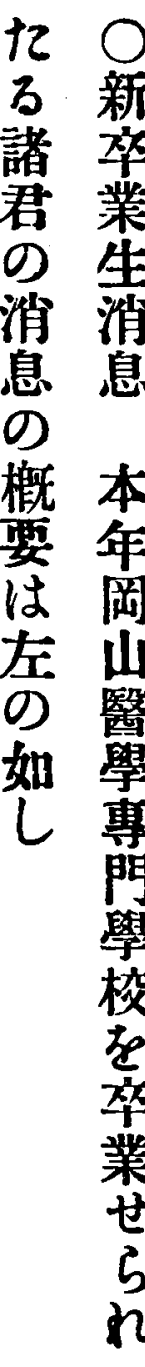 & 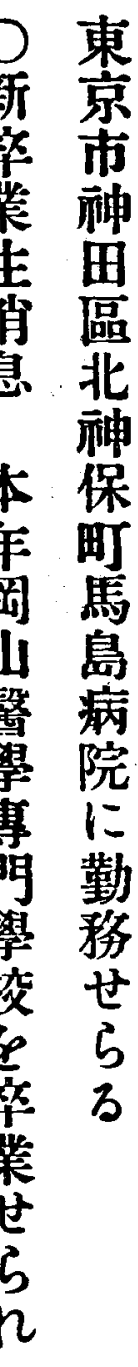 & 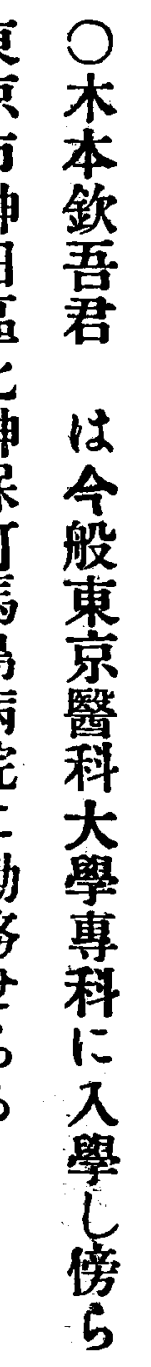 & 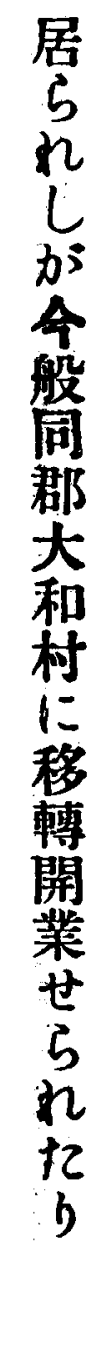 & 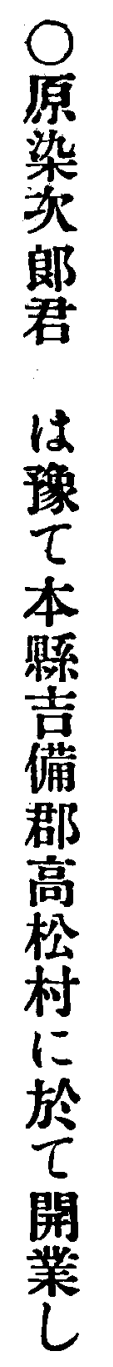 \\
\hline
\end{tabular}


葲同岡岡岡山岡岡善岡同同岡秋静岡岡善

路山山山口山通山山田山周山山通

步縣市縣榽轓市寺市

兵病熊病防病赤步石

第院谷院府院澤兵本

第第醫外町聂醫第醫 外

九 丙 丙

聯 科 科

病㗱严

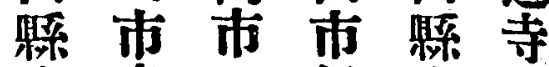

病赤三伊病步

院十番達院兵

第字町病第第

一动 伊 院 - 四

內 支 野
科部
病
院
院

內 科

安山矢柳山山陸宇上上中中武瀧糟鎌金金 田末吹井櫋縣津田田井村田谷田綱光

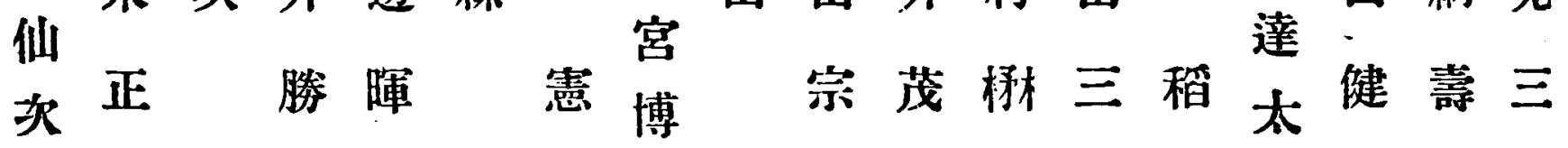
郎吉 浩人 政 修二章驍一 樹樹 郎生 郎 次 雄 郎

同同岡三岡德朝同同同同同岡岡善同岡周 山重山島鮮

縣眯䅫市 總

病富病若督

院思院林府

山山通山山

縣市寺

縣市

病 营 步

病 坂

院 病 兵

院 田

同第外浦婦病醫第耳第第皮第院第第小病

一科飯人院院

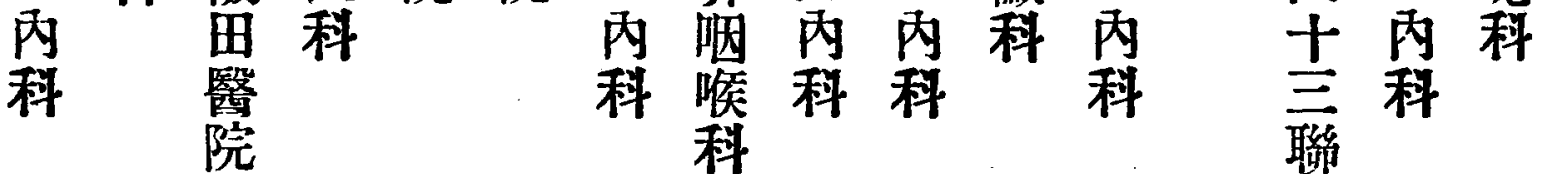

㝠 島 宮三三都三金木北木赤扇鄭小小福正松

立田本原谷田木下本村木田峉家井井 豊良常善明永正宗直義。錫 交男雄吉實治莘之治慶孝豊鎔弘郎 郎三三 
哀し $\tau$ 學 小 悼開校原 の其業を未 情效 $し$ 卒旗 に居業君 堪々方し 逝 人本几岡 ざ月し山 る三加䅫君 な十昨病は b兵年院明

日乘外治 遠病科兰 逝をに十 せ獲勤九 ら靜務年 设養し岡 けに後山

b吕郷醫

とめ里學

洵 5に專 に於阴
鳴開中米 呼業愿 悲し校彥 哉居醫三 5 學 郎 几 部 君

しをの 加來遠

去業逝

月 $し$

三鳥君

十根は

九 縣 明

日能治

·永 義 三

眠郡士

せ荒三

ら島 年

れ村第

れに䇰

b於高 と等
周同同同岡大岡 伏 山出阪山見 縣 市 縣 步 病 東 病 院 區 院 第 達 病 第 產 小第 北 外 至 院 一婦兒三 科十 內人科丙太 科科科 郎 町榢 河 野 病 院

杉砂須杉望平白滋 周田賀 月原石野 庫松韭 專太三泰久準隆至 吉 郎 郎一雄一二孝

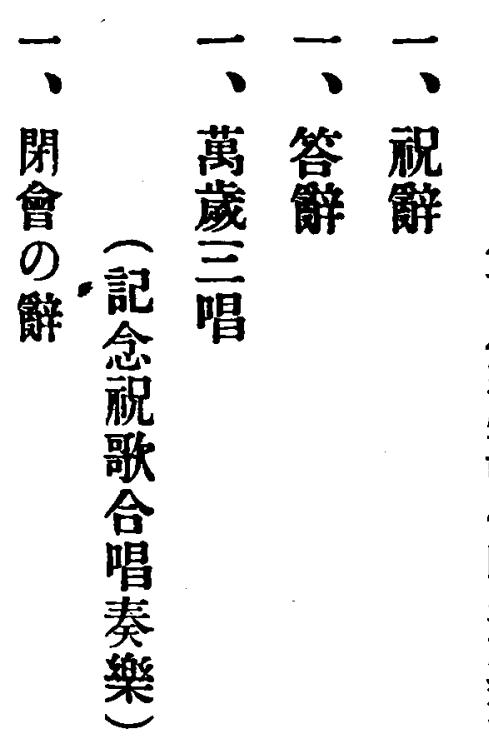

b

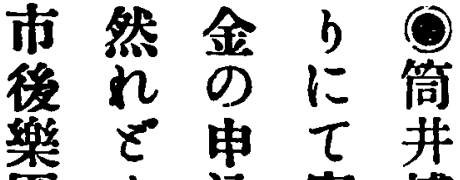

園 8 込寄 博 內其 み附士 鶴式 あ 金在 鳴はる募 擑 館豫集集三 淀以质它 於の締五 $\tau$ 如十切年 左〈月万积 の十+豫賀 順月日定會 序十迄な

に七其 $b$ 同 上旦期し 會 万午目蚻 開唛古尚九 催 - 延注月 守 時 期 續兰 万小し\&干 筈 b散日 な當 b 附 限 


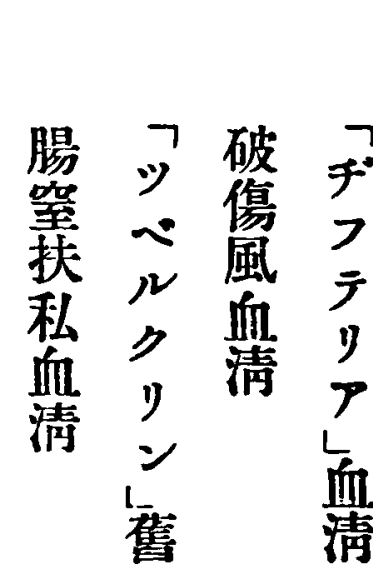

等 $\frac{\text { 第 }}{\text { 葆 }}$

，傳 傳

各染染

種 病 病

卜研 研

又究究

所所務部

二痘大大

於苗臣臣

于.

製血法法

造 清 學 學

販等 博 博

賣販士士

ス 賣

替一高

痘程木男

苗、喜

血 郎 䝰
傳

大染交

正病部岡少

四研省

年究命偕有

九 所第行志

月痘十就者

十苗三に相

四血號於謀樂

$\tau$ b

記 當

念

祝 呮

宴 賀

會 會

点 解

開 散

通定集後

万摞

筈 五

广時

\section{第 第}

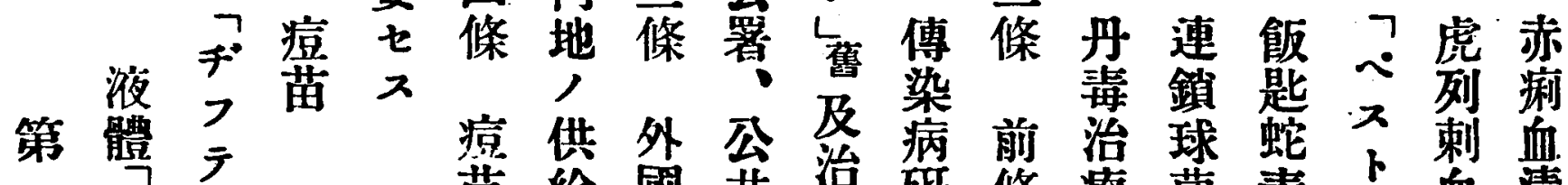

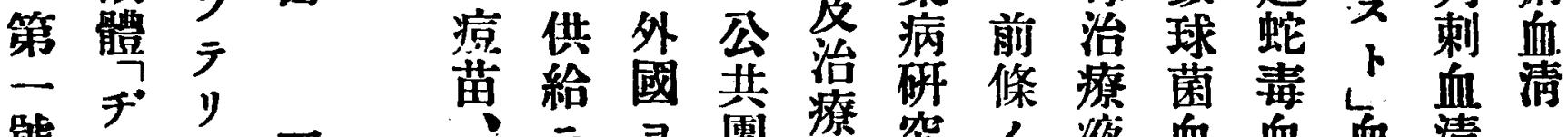

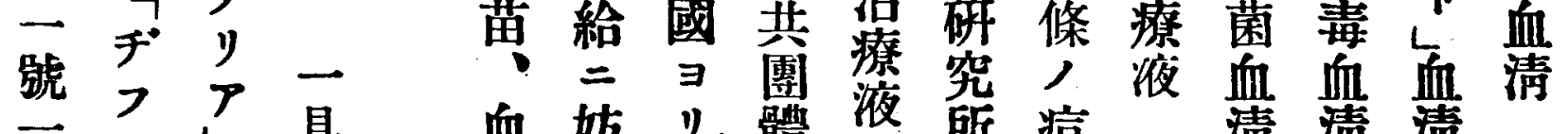

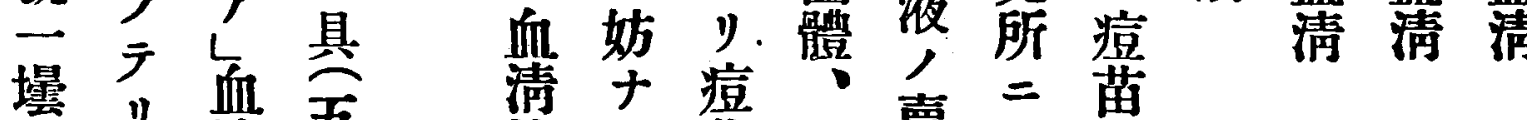

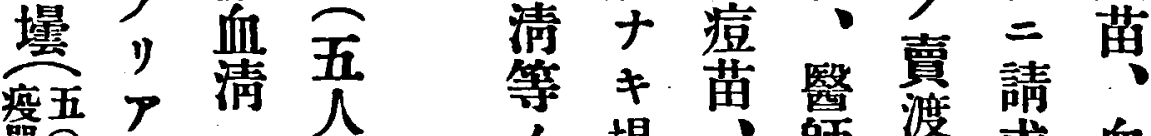

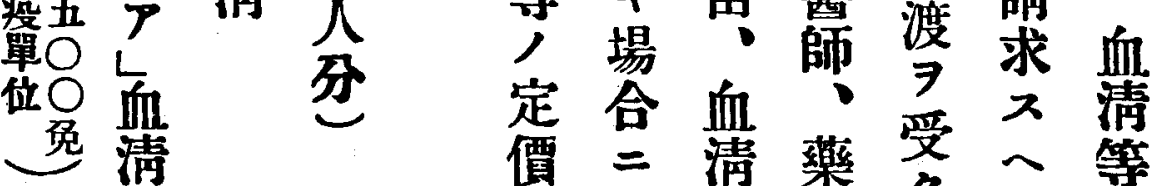

價三蔳藥受入等

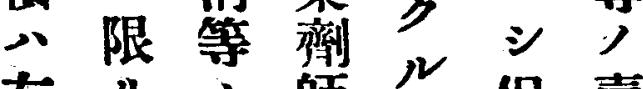

左y, 師但賣

之請又コ渡

如三洜只盀然

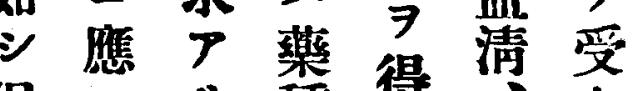

金

金但公可種得留受

鈗

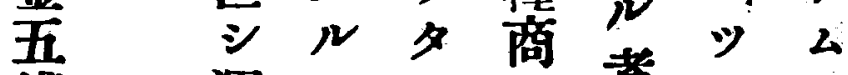

運モ心者べ

渠, r限菅公

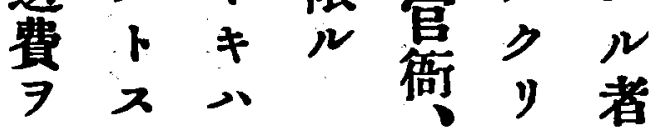




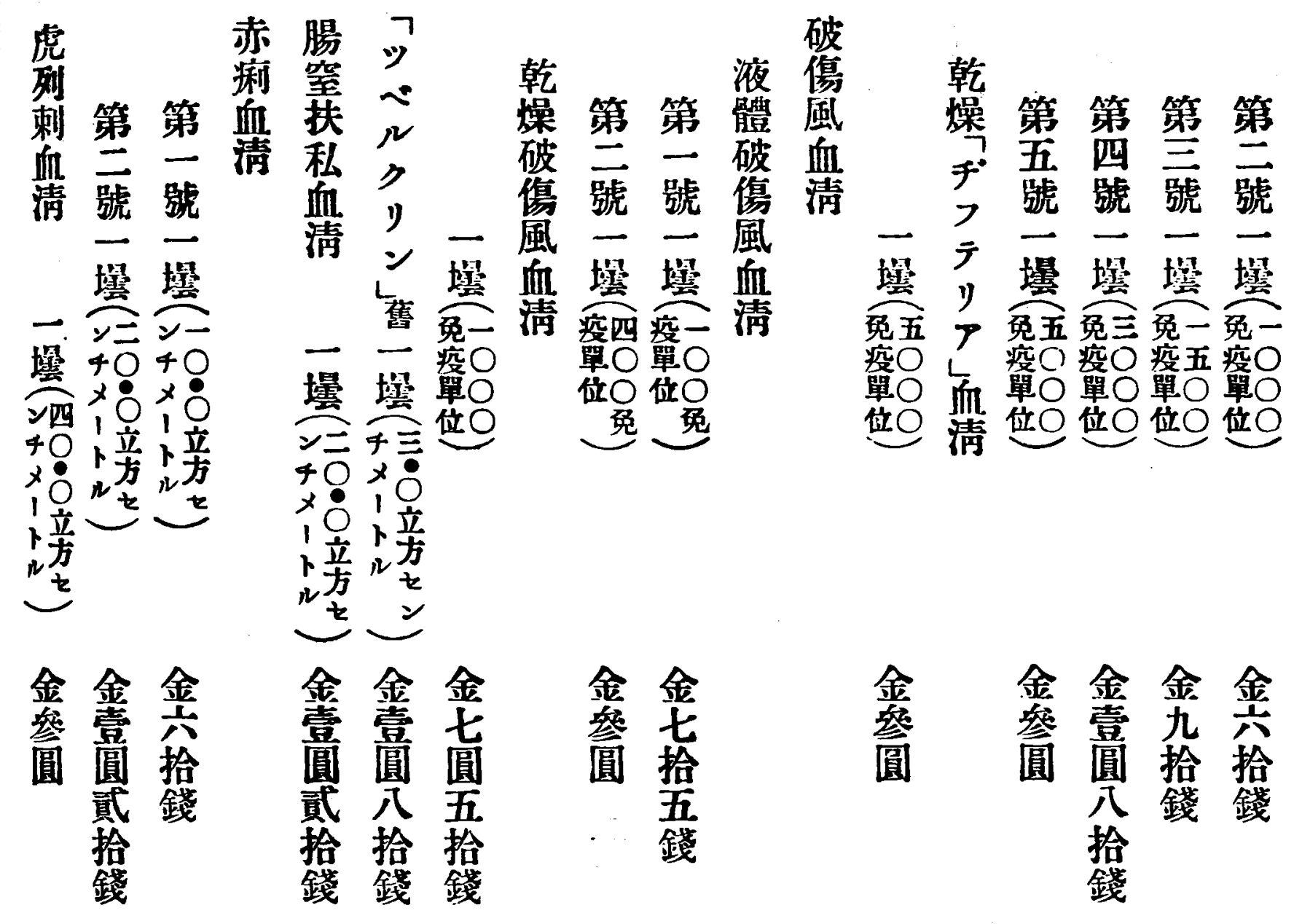

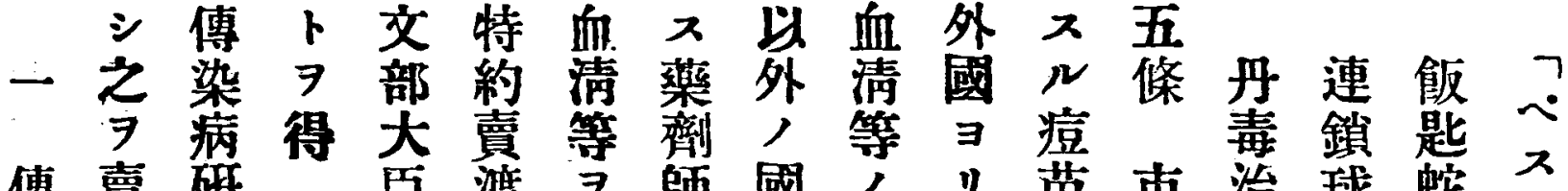
篇傳賣研臣渡寻師國了!苗市治救蛇、 血染渡究, 三通現三代，，町療菌毒 ᄂ

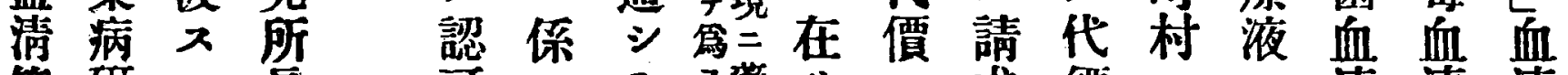

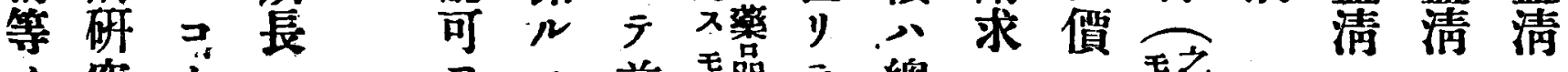
究

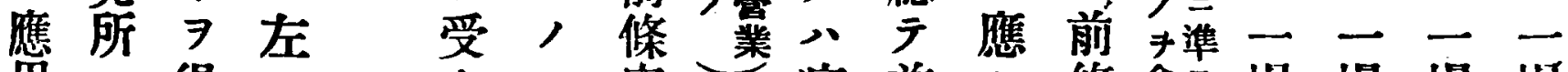

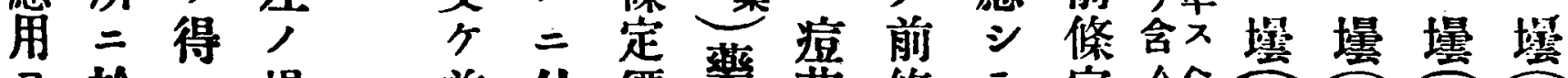

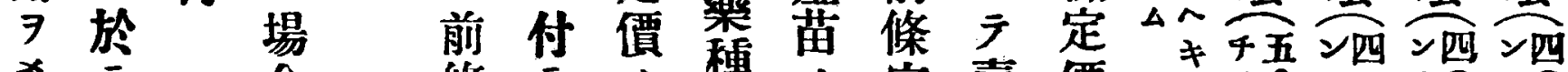

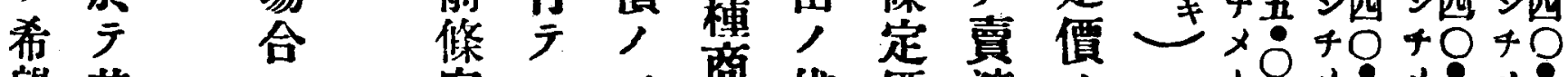
望其 = 定

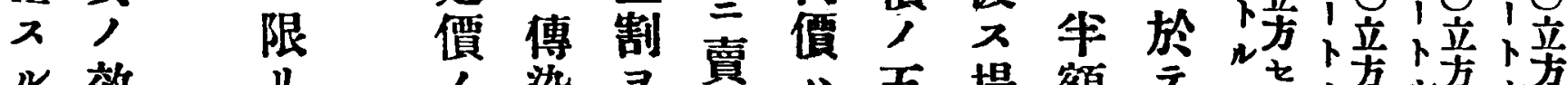
ル效り，染 $\exists$ 買八五場 額

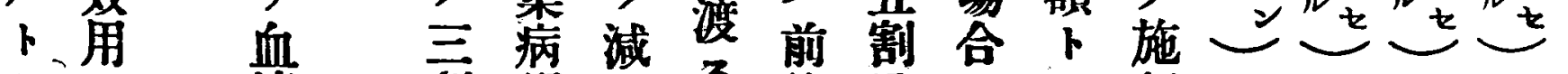

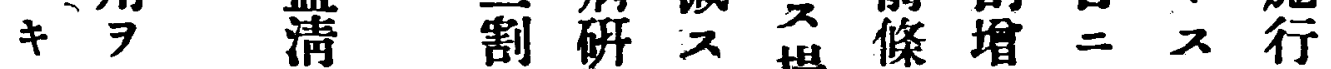

周等迄究人会代年於不金金金 定知 3 所 價七定減長但

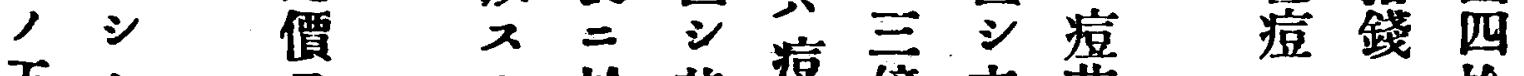
五么 $九$ 於其蒙倍支苗三拾

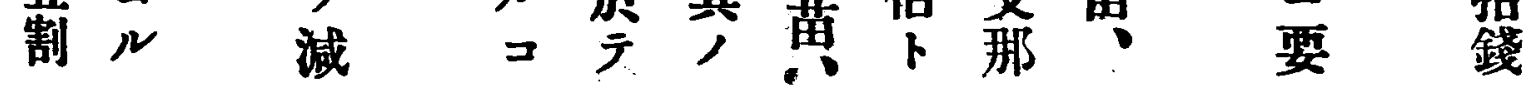


賣 明、本

渡 治 命

規 兰

則南大

$r 卜=$ 金代便

八正。

之年西附

廢務九 則

此 省 月

ス 会

第十

+ 日

號!垱

傳之

染 7

病 施

研行

究

所

痘

苗

血

入 入過條

但 不

卜 金又納條

第

足痘三代篇入痘 、及組道減

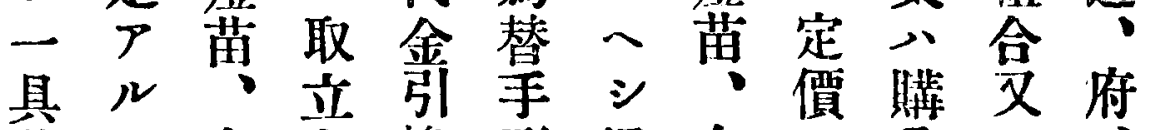

若卜血金換形但血, 入八,

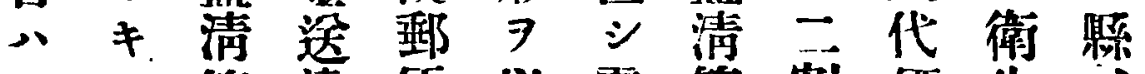

一八等澾便以電等割榎生

境代賣料二亏報, 減员會郡

今價渡 7 依逘䨋代丙二

代相請湀り金替價为於市

價當求付邆

过 $\overline{7}$ 町

$=$, 數 $入$ 付 $ル$ 郵 現

充數量人ス

夕量二シルト霹文

サ 7 對

浫 シ

場 7 替

端付納

數 $入$ 付

合 得

收

血 村

$\therefore$, ,

於

切 モ 代

捨 $/$ 價

$\bar{j}$

金印

引 紙

八換 7

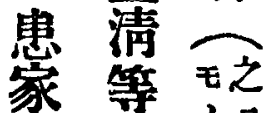

$=\exists$ 渠

供 購含

殸

代郵 以

給 入 $4 \hat{~}$

ス 诨

ル 無

卜代衛

₹ 價生

二傳日前丵 $、$ 殘ノ大 於染内項, 天品試正

病 $=$, 定新, 羷三

一䂰其請 俔定引日年 包究, 求三骦換付九 又所殘 7 充 $=7 \Gamma$ 月 八八品第多侤請 數前 $\Rightarrow$ サ 少求血干

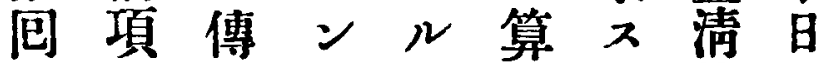
$=>$ 染卜端出ル等 $\exists$

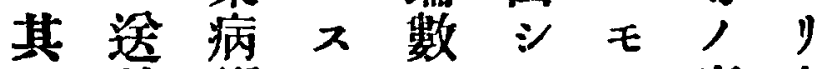
, 付䂰ル心夕, 賣本 代 $\exists$ 究者切 $=$ 渡命 品受所入捨數 $、 \exists$ 施 $\exists r=$ 本卜量其受行 交夕邀命入习, 分, 付ル付施紊舊夕日

ス日ス行 付定儿人

人 $\exists$ ス 儹者前

シリ シ 日 $\frown==日$

九 $\quad \exists$ 相 $シ$.

十少但當テテ

搨亲 